\title{
Influence of Li Addition to Zn-Al Alloys on Cu Substrate During Spreading Test and After Aging Treatment
}

\author{
TOMASZ GANCARZ (10, ${ }^{1,4,5}$ JANUSZ PSTRUS, ${ }^{1}$ GRZEGORZ CEMPURA, ${ }^{2}$ \\ and KATARZYNA BERENT ${ }^{3}$ \\ 1.-Institute of Metallurgy and Materials Science, Polish Academy of Sciences, 30-059 Kraków, \\ Poland. 2.-International Centre of Electron Microscopy for Materials Science, Faculty of Metals \\ Engineering and Industrial Computer Science, AGH University of Science and Technology, \\ Kraków, Poland. 3.-Academic Centre for Materials and Nanotechnology, AGH University of \\ Science and Technology, 30-059 Kraków, Poland. 4.-e-mail: nmgancar@imim-pan.krakow.pl. \\ 5.—e-mail: t.gancarz@imim.pl
}

The spreading of $\mathrm{Zn}-\mathrm{Al}$ eutectic-based alloys with 0.05 wt.\%, 0.1 wt.\%, and 0.2 wt.\% $\mathrm{Li}$ on $\mathrm{Cu}$ substrate has been studied using the sessile drop method in presence of QJ201 flux. Wetting tests were performed after $1 \mathrm{~min}, 3 \mathrm{~min}$, $8 \mathrm{~min}, 15 \mathrm{~min}, 30 \mathrm{~min}$, and $60 \mathrm{~min}$ of contact at temperatures of $475^{\circ} \mathrm{C}, 500^{\circ} \mathrm{C}$, $525^{\circ} \mathrm{C}$, and $550^{\circ} \mathrm{C}$. Samples after spreading at $500^{\circ} \mathrm{C}$ for $1 \mathrm{~min}$ were subjected to aging for 1 day, 10 days, and 30 days at temperature of $120^{\circ} \mathrm{C}, 170^{\circ} \mathrm{C}$, and $250^{\circ} \mathrm{C}$. The spreadability of eutectic $\mathrm{Zn}-5.3 \mathrm{Al}$ alloy with different $\mathrm{Li}$ contents on $\mathrm{Cu}$ substrate was determined in accordance with ISO 9455-10:2013-03. Selected solidified solder-substrate couples were, after spreading and aging tests, cross-sectioned and subjected to scanning electron microscopy, energydispersive spectroscopy (EDS), and x-ray diffraction (XRD) analysis of the interfacial microstructure. An experiment was designed to demonstrate the effect of $\mathrm{Li}$ addition on the kinetics of the formation and growth of $\mathrm{CuZn}$, $\mathrm{Cu}_{5} \mathrm{Zn}_{8}$, and $\mathrm{CuZn}_{4}$ intermetallic compound (IMC) phases, during spreading and aging. The IMC layers formed at the interface were identified using XRD and EDS analyses. Increasing addition of $\mathrm{Li}$ to $\mathrm{Zn}-\mathrm{Al}$ alloy caused a reduction in the thickness of the IMC layer at the interface during spreading, and an increase during aging. The activation energy was calculated, being found to increase for the $\mathrm{Cu}_{5} \mathrm{Zn}_{8}$ phase but decrease for the $\mathrm{CuZn}$ and $\mathrm{CuZn}_{4}$ phases with increasing $\mathrm{Li}$ content in the $\mathrm{Zn}-\mathrm{Al}-\mathrm{Li}$ alloys. The highest value of $142 \mathrm{~kJ} \mathrm{~mol}^{-1}$ was obtained for $\mathrm{Zn}-\mathrm{Al}$ with $1.0 \mathrm{Li}$ during spreading and $69.2 \mathrm{~kJ} \mathrm{~mol}^{-1}$ for $\mathrm{Zn}-\mathrm{Al}$ with $0.05 \mathrm{Li}$ during aging. Aging at $250^{\circ} \mathrm{C}$ caused an increase in only the $\mathrm{Cu}_{5} \mathrm{Zn}_{8}$ layer, which has the lowest Gibbs energy in the $\mathrm{Cu}-\mathrm{Zn}$ system. This result is connected to the high diffusion of $\mathrm{Cu}$ from the substrate to the solder.

Key words: $\mathrm{Zn}-\mathrm{Al}-\mathrm{Li}$, spreading test, lead-free solder, IMCs, aging, microstructure

\section{INTRODUCTION}

Addition of $\mathrm{Li}$ to $\mathrm{Al}$ alloys, ${ }^{1-3} \mathrm{Mg}$ alloys, ${ }^{4-6}$ and $\mathrm{Zn}-\mathrm{Al}$ alloys ${ }^{7}$ can improve their mechanical properties, ${ }^{1-6}$ increase their thermal properties ${ }^{1-6}$ during

(Received April 19, 2016; accepted July 18, 2016;

published online August 4, 2016) aging ${ }^{1,2}$ and soldering, ${ }^{8}$ and reduce their density. ${ }^{1}$ For Al alloys, the high concentration and significant vacancy-binding energy of $\mathrm{Li}$ atoms cause preferential clustering between $\mathrm{Li}$ atoms and quenched-in vacancies, thus retarding diffusion of $\mathrm{Zn}$ and $\mathrm{Mg}$ atoms and thereby suppressing homogeneous nucleation of Zn-rich phases in the matrix. ${ }^{1} \mathrm{Al}-\mathrm{Li}-\mathrm{Zn}-\mathrm{Mg}$ $\mathrm{Cu}$ alloys show comparable tensile properties to but 
$7 \%$ lower density than 7075 alloy. ${ }^{1}$ In the case of $\mathrm{Mg}$ alloys, AZ31 alloy with $5 \% \mathrm{Li}$ content possessed the smallest planar anisotropy and enhanced ductility. ${ }^{4}$ The excellent tensile properties of AZ31 alloys with $\mathrm{Li}$ addition were mainly attributed to the regularly arranged, grained, recrystallized microstructure. ${ }^{4}$ Intermetallic compounds (IMCs) of $\mathrm{Li}$, such as $\mathrm{Al}_{3} \mathrm{Li}^{1-3,9}$ or $\mathrm{MgLi}_{2} \mathrm{X},{ }^{4-6}$ have the main impact in terms of increasing the mechanical properties. They also have significant influence on aging and the plastic deformation process. However, the IMCs also increase the electrical resistivity, linear coefficient of thermal expansion (CTE), and hardness, ${ }^{7}$ and most importantly could block the increase of intermetallic layers, essential to the soldering process, at the solder-substrate interface. ${ }^{10}$ The characteristics of cast $\mathrm{Zn}-\mathrm{Al}$ alloys with $\mathrm{Li}$ additions were presented in Ref. 7, revealing $\mathrm{Al}_{3} \mathrm{Li}, \mathrm{AlLi}$ precipitates, and lamellar eutectic $\mathrm{Zn}$-Al structure $(\alpha+\eta)$ in the microstructure. Mechanical and thermal properties increased with increasing $\mathrm{Li}$ content. In literature data, there is no information about the influence of $\mathrm{Li}$ addition on the formation and growth of IMC layers during the soldering process. During a similar spreading process, added $\mathrm{Ag},{ }^{10} \mathrm{Cu},{ }^{11}$ and $\mathrm{Na}^{12}$ formed an IMC with $\mathrm{Zn}$ that blocked the growth of an IMC from the $\mathrm{Cu}-\mathrm{Zn}$ system layer at the interface. The resulting $\mathrm{AgZn}_{3}, \mathrm{Cu}_{5} \mathrm{Zn}_{8}$ and $\mathrm{CuZn}_{4}$, and $\mathrm{NaZn}_{13}$ precipitates, in $\mathrm{Zn}-\mathrm{Al}-\mathrm{Ag},{ }^{10} \mathrm{Zn}-\mathrm{Al}-\mathrm{Cu},{ }^{11}$ and $\mathrm{Zn}-\mathrm{Al}-\mathrm{Na},{ }^{12}$ respectively, blocked diffusion of $\mathrm{Zn}$ to the interface, which was connected with the $\mathrm{Zn}$ in the IMCs. On transmission electron microscopy investigation of the microstructure of $\mathrm{Zn}-\mathrm{Al}-\mathrm{Li}$ cast alloys, very small precipitates were found in the $\mathrm{Zn}$ area; although they could not be identified, they might be IMCs from the Li-Zn system, ${ }^{13}$ such as $\mathrm{Li}_{2} \mathrm{Zn}_{3}, \mathrm{LiZn}_{2}, \mathrm{Li}_{2} \mathrm{Zn}_{5}$, and $\mathrm{LiZn}_{4}$, or the ternary $\mathrm{Al}-$ $\mathrm{Li}-\mathrm{Zn}$ system, ${ }^{13}$ such as $\tau_{1}\left(\mathrm{Li}_{1+x} \mathrm{Zn}_{0.5-1.5} \mathrm{Al}_{0.5-1.5}\right)$, $\tau_{2}\left(\mathrm{LiZn}_{0.6-0.8} \mathrm{Al}_{0.4-0.2}\right), \tau_{3}\left(\mathrm{LiZn}_{3} \mathrm{Al}\right)$, and $\tau_{4}\left(\mathrm{Li}_{3} \mathrm{Z}-\right.$ $\mathrm{nAl}_{5}$ ). Calorimetry measurements ${ }^{7}$ revealed a widening of the characteristic peaks, at around $280^{\circ} \mathrm{C}$ for the $\alpha$ to $\alpha^{\prime}$ reaction and around $380^{\circ} \mathrm{C}$ for the melting reaction, ${ }^{14}$ which could correspond to liq. $+\mathrm{Al}_{2} \mathrm{Li}_{3} \rightarrow \mathrm{Al}_{4} \mathrm{Li}_{9}+\mathrm{AlLi}$ and liq. $\rightarrow \tau_{3}+\mathrm{hcp}+$ $\beta$-LiZn 4 , respectively. ${ }^{7}$

Zn-base solders with alloying elements were further developed for ultrahigh-temperature applications. ${ }^{15}$ Previous studies on $\mathrm{Zn}-\mathrm{Al}-\mathrm{Ag},{ }^{10} \mathrm{Zn}-\mathrm{Al}-$ $\mathrm{Cu},{ }^{11}$ and $\mathrm{Zn}-\mathrm{Al}-\mathrm{Na}^{12}$ and literature data for $\mathrm{Zn}-\mathrm{Al}-$ $\mathrm{Cu}^{16,17}$ and $\mathrm{Zn}-\mathrm{Al}-\mathrm{Mg}-\mathrm{Ga}^{18}$ describe the influence of time, temperature, and alloying elements in the spreading process on the spreadability and the growth of the IMC layers at the interface. These studies reveal that small addition of alloying elements reduces the IMC layers at the interface, and that increasing time and temperature caused increasing diffusion of $\mathrm{Cu}$ to the solder and the growth of IMC layers, most notably the $\mathrm{Cu}_{5} \mathrm{Zn}_{8}$ layer, which has the lowest Gibbs energy. ${ }^{11}$ Moreover, the $\mathrm{Al}-\mathrm{Li}$ precipitates formed in the solder could block diffusion of $\mathrm{Al}$ to the interface, which should slow down formation of $\mathrm{Al}_{4} \mathrm{Cu}_{9}$ phase at the interface inside the $\mathrm{Cu}_{5} \mathrm{Zn}_{8}$ layer. This is in accordance with the phase diagram of the $\mathrm{Al}-\mathrm{Cu}-\mathrm{Zn}$ system. ${ }^{19}$ The aim of this study is to demonstrate the effect of $\mathrm{Li}$ addition on the kinetics of formation and growth of the $\mathrm{CuZn}, \mathrm{Cu}_{5} \mathrm{Zn}_{8}$, and $\mathrm{CuZn}_{4}$ phases, in the spreading process and after aging treatment.

\section{EXPERIMENTAL PROCEDURES}

Cast eutectic $\mathrm{Zn}-5.3 \mathrm{Al}$ alloys with 0.05 wt.\%, 0.1 wt. $\%$, and 0.2 wt. $\% \mathrm{Li}^{7}(\mathrm{Zn}-\mathrm{Al}+\mathrm{Li})$ were studied in air using the sessile drop method in presence of QJ201 flux. Experiments without flux were unsuccessful, as the solder surface oxidized, resulting in failure to connect with the $\mathrm{Cu}$ substrate. Therefore, QJ201 flux from powder, consisting of $50 \mathrm{wt} . \% \mathrm{KCl}$, 32 wt. $\% \mathrm{LiCl}, 10$ wt. $\% \mathrm{NaF}$, and 8 wt. $\% \mathrm{ZnCl}_{2}$, was applied for protection and oxide removal. Spreading tests were performed after $1 \mathrm{~min}, 3 \mathrm{~min}, 8 \mathrm{~min}$, $15 \mathrm{~min}, 30 \mathrm{~min}$, and $60 \mathrm{~min}$ of contact at temperatures of $475^{\circ} \mathrm{C}, 500^{\circ} \mathrm{C}, 525^{\circ} \mathrm{C}$, and $550^{\circ} \mathrm{C}$. As described in Refs. 7 and 10, the spreading area of 0.5-g samples of Zn-Al-Li solder was calculated after cleaning flux residue from solidified samples. The spreading area was calculated using the Get Area script in CorelDRAW 12. The margin of error for measurements was 5\%, as described in Ref. 10. The time and temperature dependence of the spreadability of $\mathrm{Zn}-\mathrm{Al}+\mathrm{Li}$ on $\mathrm{Cu}$ was determined. Samples after the spreading test at $500^{\circ} \mathrm{C}$ for 1 min were subjected to aging for 1 day, 10 days, and 30 days at $120^{\circ} \mathrm{C}, 170^{\circ} \mathrm{C}$, and $250^{\circ} \mathrm{C}$. The aging process was conducted in an electrical furnace in air. Half of the selected samples were placed in the furnace for the appropriate time and at the appropriate temperature. The growth rate and activation energy of the $\mathrm{Cu}_{5} \mathrm{Zn}_{8}$ layer in solid state were determined during the spreading test and aging. Selected soldersubstrate couples were cut perpendicular to the plane of the interface using a diamond wire saw, then mounted in conductive resin, ground, polished, covered with a thin layer of $\mathrm{C}$ to protect from oxygen, and subjected to microstructural and elemental analyses by scanning electron microscopy (SEM) coupled with energy-dispersive spectrometry (EDS) and x-ray diffraction (XRD) analysis, to study the interfacial microstructure and IMCs occurring at the interface. The thickness of the IMC layer $(D)$ is dependent on the growth rate $(k)$ and growth time $(t)$ with an exponential factor $(n)$ :

$$
D=k(t)^{n} \text {. }
$$

The growth rate for interface migration can be described by an Arrhenius-type equation (2):

$$
k=k_{0} \exp \left(-\frac{Q}{R T}\right),
$$

where $k_{0}, Q, R$, and $T$ represent the migration rate constant, the activation energy, the universal gas constant, and absolute temperature, respectively. 
The initial thickness of each IMC layer after the aging process should be taken into account, and Eq. 1 should be modified to

$$
\Delta x=d_{0}+k t^{n}
$$

where $\Delta x$ is the average thickness of the IMC layer, $d_{0}$ is the initial thickness of the IMC layer, $k$ is the growth rate coefficient, and $t$ is the aging duration.

\section{RESULTS AND DISCUSSION}

\section{Spreading Test}

In previous study, ${ }^{7}$ the characteristics of cast $\mathrm{Zn}$ $\mathrm{Al}-\mathrm{Li}$ alloys were presented. The influence of $\mathrm{Li}$ addition on the thermal and mechanical properties, which were increased due to the formation of IMC precipitates, can be seen in the microstructure using transmission electron microscopy and XRD. However, the high reactivity of $\mathrm{Li}$, the impossibility of using EDS analysis, and the lack of literature and crystal structure data mean that only $\mathrm{AlLi}$ and $\mathrm{Al}_{3} \mathrm{Li}$ precipitates could be identified in cast $\mathrm{Zn}-\mathrm{Al}$ Li alloys. ${ }^{7}$ Furthermore, calorimetry measurements showed the possibility that the $\tau_{3}$ present corresponds to $\mathrm{LiZn}_{3} \mathrm{Al}$, which could have a decisive impact on the diffusion of $\mathrm{Zn}$ to the interface. ${ }^{7}$ The connection of $\mathrm{Zn}$ with the formed IMCs, as shown in Ref. 10 for Ag addition, causes a reduction in the thickness of IMC layers at the interface. Regarding the soldering process, the spreading area of $\mathrm{Zn}-\mathrm{Al}-\mathrm{Li}$ alloys for the spreading test at $500^{\circ} \mathrm{C}$ after $1 \mathrm{~min}$, $3 \mathrm{~min}, 8 \mathrm{~min}, 15 \mathrm{~min}, 30 \mathrm{~min}$, and $60 \mathrm{~min}$ of contact, and at temperatures of $475^{\circ} \mathrm{C}, 500^{\circ} \mathrm{C}, 525^{\circ} \mathrm{C}$, and $550^{\circ} \mathrm{C}$ after $8 \mathrm{~min}$, are shown in Fig. 1a and b, respectively. Generally, compared with eutectic $\mathrm{Zn}$ $\mathrm{Al}$, increased spreading area was observed for $\mathrm{Zn}-\mathrm{Al}$ alloys with $\mathrm{Li}$ addition. The highest growth in the time and temperature dependences was observed for $\mathrm{Zn}-\mathrm{Al}-0.05 \mathrm{wt} . \% \mathrm{Li}$. However, increasing the $\mathrm{Li}$ content in the eutectic $\mathrm{Zn}-\mathrm{Al}$ caused the spreading area to reduce, reaching its lowest value for $\mathrm{Zn}-\mathrm{Al}$ $0.2 \mathrm{Li}$. Similar effects have been observed in terms of reduced spreading area with increasing addition of $\mathrm{Ag}^{10}$ and $\mathrm{Cu}^{16}$ to eutectic $\mathrm{Zn}-\mathrm{Al}$. This could result in creation of IMC precipitates which are not dissolved in the solder during the spreading test, or shortrange ordering (creation of associates) in the liquid. $^{20}$ These two mechanisms reduce the volume of liquid and increase its density, ${ }^{20}$ which reduces the spreading area.

Figure 2 shows the cross-sectional microstructure of $\mathrm{Zn}-\mathrm{Al}$ with 0.05 wt.\% $\mathrm{Li}$ alloy on $\mathrm{Cu}$ substrates after the spreading test at temperature of $500^{\circ} \mathrm{C}$ for times of (a) $1 \mathrm{~min}$, (b) $3 \mathrm{~min}$, (c) $8 \mathrm{~min}$, (d) $15 \mathrm{~min}$, (e) $30 \mathrm{~min}$, and (f) $60 \mathrm{~min}$. In the microstructure at the solder-Cu substrate interface, IMC layers from the $\mathrm{Cu}-\mathrm{Zn}$ system form. Three IMC layers $(\mathrm{CuZn}$, $\mathrm{Cu}_{5} \mathrm{Zn}_{8}$, and $\mathrm{CuZn}_{4}$ ) were observed to occur at the interface from the $\mathrm{Cu}$ substrate side, as shown in previous work and literature data. ${ }^{10-12,15,17,21}$ All IMC layers grew with increasing time, with the highest growth for the $\mathrm{Cu}_{5} \mathrm{Zn}_{8}$ layer; similar thickness of $\mathrm{Cu}_{5} \mathrm{Zn}_{8}$ layer was observed in literature data. ${ }^{10-12,15,17,21}$ Analysis of Li by SEM-EDS was below the detection level, so EDS analysis of $\mathrm{Li}$ is not reported in Table I. At the beginning of spreading $(1 \mathrm{~min}$ to $8 \mathrm{~min})$, the thicknesses of $\mathrm{Cu}_{5} \mathrm{Zn}_{8}$ and $\mathrm{CuZn}_{4}$ were similar. With increasing time $(15 \mathrm{~min}$ to $60 \mathrm{~min}), \mathrm{Cu}_{5} \mathrm{Zn}_{8}$ grew the fastest, due to the diffusion of $\mathrm{Cu}$ and its having the lowest Gibbs energy of the phases formed at the interface. ${ }^{10,12}$ Similar to earlier work on $\mathrm{Zn}$-Al with $\mathrm{Ag},{ }^{10} \mathrm{Cu},{ }^{11,17}$ $\mathrm{Na}^{12}$ and $\mathrm{Si}^{22}$ three IMCs from the $\mathrm{Cu}-\mathrm{Zn}$ system formed at the interface. The $\mathrm{CuZn}_{4}$ layer with scallop-shaped morphology, which become detached and moved into the solder, and the greater thickness of the $\mathrm{Cu}_{5} \mathrm{Zn}_{8}$ phase, show the fast path for $\mathrm{Cu}$ diffusion and the thin, smooth CuZn layer.
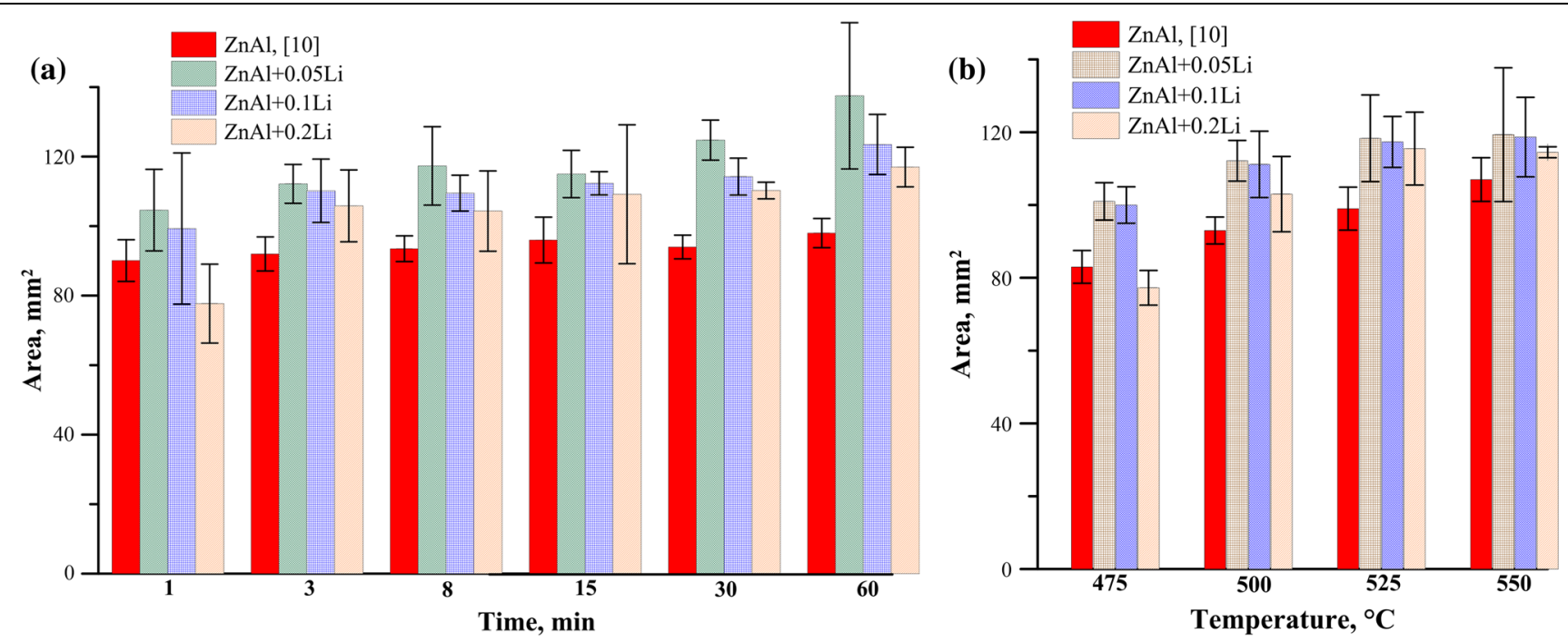

Fig. 1. Spreading area of $\mathrm{Zn}-\mathrm{Al}$ alloys with $\mathrm{Li}$ addition: (a) time and (b) temperature dependence. 


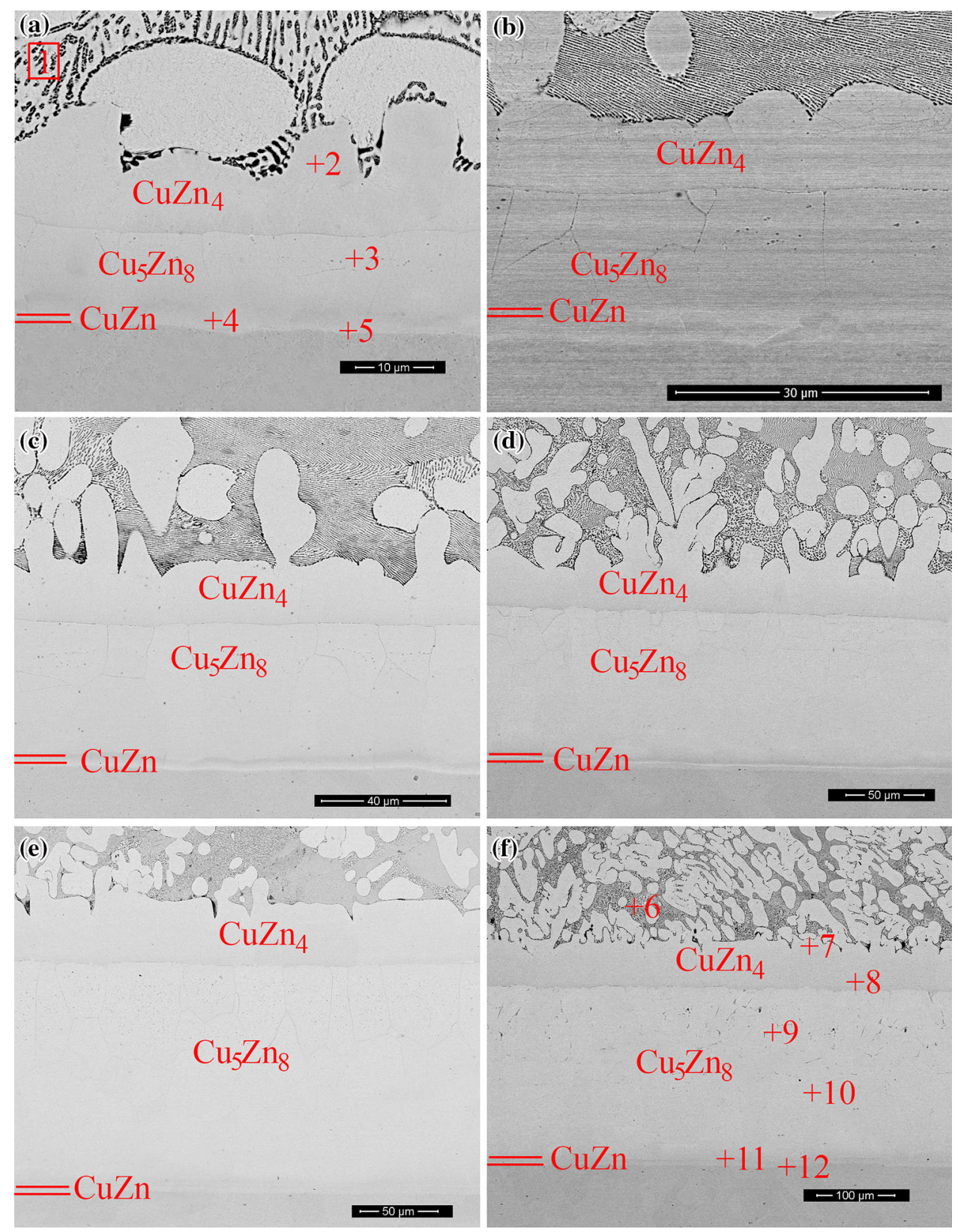

Fig. 2. Microstructure of interfaces on cross-sections of $\mathrm{Zn}-\mathrm{Al}+0.05 \mathrm{Li}$ alloy on $\mathrm{Cu}$ substrate after spreading test at temperature of $500^{\circ} \mathrm{C}$ for times of (a) $1 \mathrm{~min}$, (b) $3 \mathrm{~min}$, (c) $8 \mathrm{~min}$, (d) $15 \mathrm{~min}$, (e) $30 \mathrm{~min}$, and (f) $60 \mathrm{~min}$, with IMCs and EDS analysis points marked (values presented in Table I).

However, the different character of the IMC layer formed at the beginning of spreading has a significant impact on the growth and the diffusion of $\mathrm{Cu}$ to the interface.

Figure $3 \mathrm{a}-\mathrm{c}$ presents the thicknesses of the IMC layers formed at the interface at temperature of $500^{\circ} \mathrm{C}$ and time from $1 \mathrm{~min}$ to $60 \mathrm{~min}$, for $\mathrm{Zn}$-Al with 0.2 wt. $\%, 0.5$ wt. $\%$, and 1.0 wt. $\% \mathrm{Li}$ addition, respectively. At the beginning of the spreading test ( $1 \mathrm{~min}$ to $8 \mathrm{~min}$ ), the thicknesses of the $\mathrm{Cu}_{5} \mathrm{Zn}_{8}$ and $\mathrm{CuZn}_{4}$ layers are almost the same. After $15 \mathrm{~min}$, the $\mathrm{Cu}_{5} \mathrm{Zn}_{8}$ was the thickest. A different character of the growth of IMC layers was observed for $\mathrm{Zn}$ -
$\mathrm{Al}+\mathrm{Ag}^{10}$ and $\mathrm{Zn}-\mathrm{Al}+\mathrm{Na},{ }^{12}$ with higher growth of $\mathrm{Cu}_{5} \mathrm{Zn}_{8}$ being observed after just $3 \mathrm{~min}$. This could be caused by $\mathrm{Cu}-\mathrm{Zn}$ system layers formed above the interface. Figure 4 shows the high amount of $\mathrm{Al}-\mathrm{Li}$ precipitates, which block diffusion of $\mathrm{Zn}$ to the interface and inhibit the growth of the $\mathrm{CuZn}_{4}$ and $\mathrm{Cu}_{5} \mathrm{Zn}_{8}$ phases. Preparation of foils for TEM microstructure observations was very difficult because the samples were brittle and cracked at the interface as a result of residual stresses, as indicated by the scanning transmission electron microscopy (STEM) images in Fig. 4a. According to Date et al., ${ }^{23}$ the observed $\mathrm{Cu}_{5} \mathrm{Zn}_{8}$ layer thickening 
Table I. EDS analysis of Zn-Al alloys with $\mathrm{Li}$ at points marked in Figs. 2, 5, and 8-10

\begin{tabular}{|c|c|c|c|c|c|c|}
\hline \multirow[b]{2}{*}{ Marked point } & \multicolumn{3}{|c|}{ wt.\% } & \multicolumn{3}{|c|}{ at. $\%$} \\
\hline & $\mathbf{A l}^{\mathbf{K}}$ & $\mathbf{C u}^{\mathrm{K}}$ & $\mathbf{Z n}^{\mathbf{K}}$ & $\mathbf{A l}^{\mathbf{K}}$ & $\mathbf{C u}^{\mathrm{K}}$ & $\mathbf{Z n}^{\mathbf{K}}$ \\
\hline 1 & 8.1 & 4.1 & 87.9 & 17.5 & 3.7 & 78.8 \\
\hline 2 & 1.2 & 17.4 & 81.5 & 2.7 & 17.5 & 79.8 \\
\hline 3 & 4.0 & 41.3 & 54.8 & 9.0 & 39.7 & 51.3 \\
\hline 4 & 8.3 & 55.6 & 36.1 & 17.8 & 50.4 & 31.8 \\
\hline 5 & 4.4 & 47.5 & 48.1 & 9.9 & 45.4 & 44.7 \\
\hline 6 & 10.6 & 3.7 & 85.7 & 22.3 & 3.3 & 74.4 \\
\hline 7 & 1.7 & 19.4 & 79.0 & 3.9 & 19.4 & 76.7 \\
\hline 8 & 3.1 & 29.2 & 67.6 & 7.2 & 28.6 & 64.3 \\
\hline 9 & 13.1 & 54.4 & 32.5 & 26.4 & 46.6 & 27.0 \\
\hline 10 & 4.5 & 47.1 & 48.4 & 10.2 & 45.0 & 44.9 \\
\hline 11 & 3.0 & 55.4 & 41.6 & 6.8 & 53.9 & 39.3 \\
\hline 12 & 2.0 & 57.9 & 40.0 & 4.7 & 57.0 & 38.3 \\
\hline 13 & 8.1 & 3.7 & 88.2 & 17.6 & 3.4 & 79.0 \\
\hline 14 & 1.2 & 18.2 & 80.7 & 2.8 & 18.3 & 78.9 \\
\hline 15 & 1.7 & 21.5 & 76.9 & 4.0 & 21.4 & 74.6 \\
\hline 16 & 5.9 & 49.3 & 44.9 & 12.9 & 46.2 & 40.9 \\
\hline 17 & 8.0 & 55.6 & 36.4 & 17.1 & 50.7 & 32.2 \\
\hline 18 & 4.4 & 52.0 & 43.6 & 9.9 & 49.6 & 40.5 \\
\hline 19 & 6.3 & 3.6 & 90.1 & 14.0 & 3.4 & 82.6 \\
\hline 20 & 2.7 & 26.3 & 70.9 & 6.3 & 25.9 & 67.8 \\
\hline 21 & 1.2 & 34.1 & 64.8 & 2.8 & 34.1 & 63.1 \\
\hline 22 & 5.3 & 48.8 & 45.9 & 11.8 & 46.0 & 42.2 \\
\hline 23 & 7.6 & 58.0 & 34.5 & 16.3 & 53.0 & 30.7 \\
\hline 24 & 5.3 & 55.1 & 39.6 & 11.8 & 51.9 & 36.3 \\
\hline 25 & 7.1 & 3.0 & 89.9 & 15.7 & 2.8 & 81.6 \\
\hline 26 & 1.0 & 15.7 & 83.3 & 2.5 & 15.8 & 81.7 \\
\hline 27 & 1.3 & 17.9 & 80.8 & 3.1 & 18.0 & 78.9 \\
\hline 28 & 2.1 & 22.5 & 75.5 & 4.8 & 22.3 & 72.9 \\
\hline 29 & 3.3 & 40.9 & 55.8 & 7.6 & 39.7 & 52.7 \\
\hline 30 & 3.8 & 41.9 & 54.3 & 8.7 & 40.4 & 50.9 \\
\hline 31 & 8.6 & 56.0 & 35.4 & 18.3 & 50.6 & 31.1 \\
\hline 32 & 5.7 & 49.8 & 44.6 & 12.6 & 46.8 & 40.7 \\
\hline 33 & 9.4 & 3.7 & 87.0 & 20.0 & 3.3 & 76.7 \\
\hline 34 & 2.1 & 2.5 & 95.4 & 5.0 & 2.5 & 92.5 \\
\hline 35 & 1.6 & 18.5 & 79.8 & 3.9 & 18.5 & 77.6 \\
\hline 36 & 0.9 & 33.3 & 65.8 & 2.0 & 33.6 & 64.4 \\
\hline 37 & 23.7 & 63.4 & 12.9 & 42.4 & 48.1 & 9.5 \\
\hline 38 & 12.7 & 62.4 & 25.0 & 25.6 & 53.5 & 20.9 \\
\hline 39 & 6.0 & 47.7 & 46.4 & 13.2 & 44.6 & 42.2 \\
\hline 40 & 8.6 & 4.8 & 86.6 & 18.5 & 4.4 & 77.1 \\
\hline 41 & 1.5 & 3.8 & 94.7 & 3.5 & 3.9 & 92.7 \\
\hline 42 & 1.3 & 18.6 & 80.1 & 3.2 & 18.6 & 78.2 \\
\hline 43 & 0.7 & 19.8 & 79.5 & 1.6 & 20.1 & 78.3 \\
\hline 44 & 1.4 & 36.9 & 61.7 & 3.3 & 36.8 & 59.9 \\
\hline 45 & 11.5 & 55.6 & 33.0 & 23.6 & 48.5 & 28.0 \\
\hline 46 & 5.7 & 48.8 & 45.5 & 12.7 & 45.8 & 41.5 \\
\hline 47 & 26.9 & 48.3 & 24.8 & 46.6 & 35.6 & 17.8 \\
\hline 48 & 1.8 & 4.3 & 93.9 & 4.3 & 4.3 & 91.5 \\
\hline 49 & 8.2 & 5.3 & 86.6 & 17.7 & 4.9 & 77.5 \\
\hline 50 & 34.7 & 56.1 & 9.3 & 55.7 & 38.2 & 6.1 \\
\hline 51 & 13.8 & 72.8 & 13.4 & 27.5 & 61.5 & 11.0 \\
\hline 52 & 1.1 & 38.7 & 60.2 & 2.7 & 38.7 & 58.6 \\
\hline 53 & 1.3 & 39.1 & 59.6 & 3.0 & 39.1 & 58.0 \\
\hline 54 & 10.4 & 3.9 & 85.7 & 21.9 & 3.5 & 74.6 \\
\hline 55 & 0.6 & 3.0 & 96.4 & 1.4 & 3.1 & 95.5 \\
\hline 56 & 67.5 & 0.0 & 32.5 & 83.4 & 0.0 & 16.6 \\
\hline 57 & 32.5 & 56.8 & 10.7 & 53.2 & 39.5 & 7.3 \\
\hline 58 & 11.9 & 55.2 & 32.9 & 24.3 & 47.9 & 27.8 \\
\hline 59 & 2.1 & 39.7 & 58.2 & 4.8 & 39.3 & 55.9 \\
\hline 60 & 2.2 & 39.7 & 58.1 & 5.1 & 39.2 & 55.8 \\
\hline
\end{tabular}


(a)

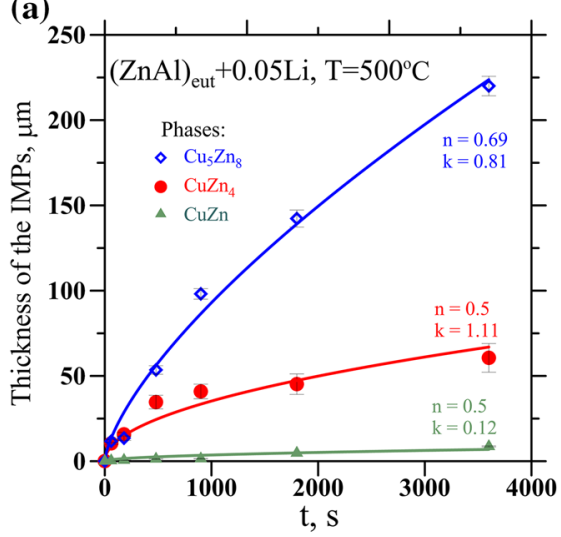

(b)

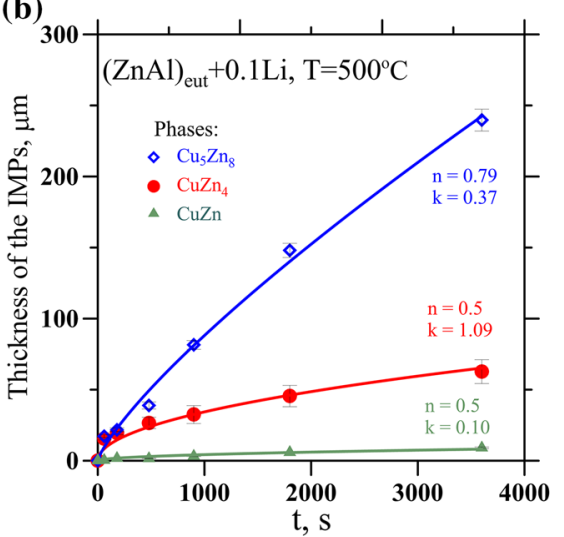

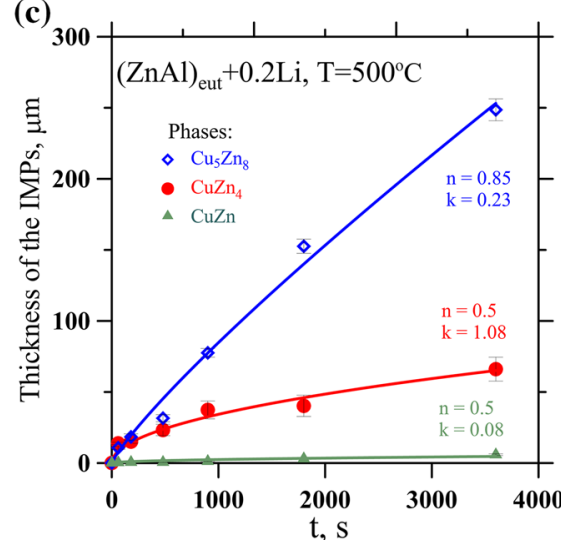

Fig. 3. Dependence of IMC thicknesses on time for (a) 0.05 wt.\%, (b) 0.1 wt.\%, and (c) 0.2 wt.\% Li addition to eutectic Zn-Al.
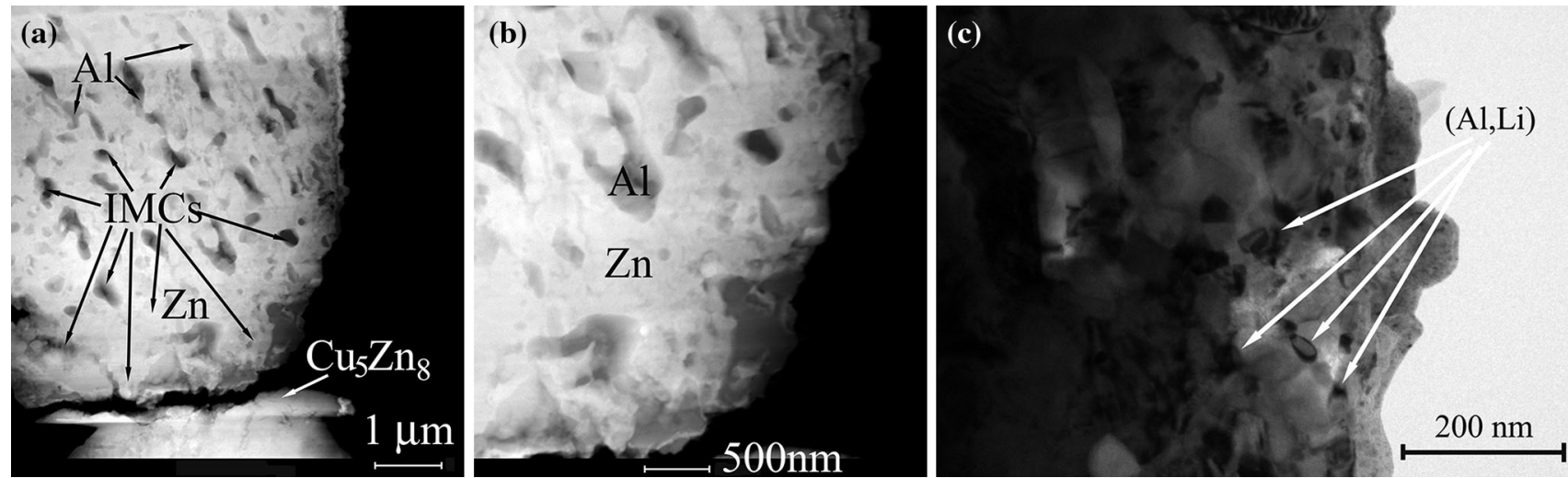

Fig. 4. TEM microstructure: (a, b) scanning transmission electron microscopy (STEM), (c) high-angle annular dark field (HAADF).

and void formation accounted for the brittleness of the solder $/ \mathrm{Cu}$. The precipitates from the $\mathrm{Al}-\mathrm{Li}$ system observed in the high-angle annular dark field (HAADF) image in Fig. 4c were identified in cast alloys as $\mathrm{Al}_{3} \mathrm{Li}$ and $\mathrm{AlLi} .{ }^{7}$ Moreover, the lowest thickness of IMC layers $(289.3 \mu \mathrm{m})$ was obtained for 0.05 wt.\% $\mathrm{Li}$ content. With increasing $\mathrm{Li}$ content in the $\mathrm{Zn}$-Al-Li alloys, the thickness increased slightly (to $311.5 \mu \mathrm{m}$ and $320.6 \mu \mathrm{m}$ for $0.1 \mathrm{wt} . \%$ and 0.2 wt.\% Li, respectively) after $60 \mathrm{~min}$. The obtained thicknesses of the IMC layers were slightly lower compared with eutectic $\mathrm{Zn}-\mathrm{Al}{ }^{10}$ but similar to $\mathrm{Zn}-\mathrm{Al}$ with addition of $\mathrm{Ag},{ }^{10} \mathrm{Cu},{ }^{17}$ and $\mathrm{Na} .{ }^{12}$ The greatest growth of $\mathrm{Cu}_{5} \mathrm{Zn}_{8}$ corresponds to the highest stability of the $\mathrm{Cu}_{5} \mathrm{Zn}_{8}$ phase and high diffusion of $\mathrm{Cu}$ and $\mathrm{Zn}$ to the interface. The $n$ parameter indicates the diffusion character, with $n=0.5$ indicating control by volume diffusion and $n=1$ a chemical reaction. For the $\mathrm{Cu}_{5} \mathrm{Zn}_{8}$ phase, increase in the $n$ parameter with increasing $\mathrm{Li}$ addition was observed, being $0.69,0.79$, and 0.85 for 0.05 wt.\%, $0.1 \mathrm{wt} . \%$, and $0.2 \mathrm{wt} . \% \mathrm{Li}$. This rise of $n$ corresponds to increasing chemical reaction in the formation process of the $\mathrm{Cu}_{5} \mathrm{Zn}_{8}$ layer with increasing $\mathrm{Li}$ addition. This could be caused by precipitates of Al$\mathrm{Li}$, corresponding to the higher amount of $\mathrm{Zn}$ in the $\mathrm{Zn}-\mathrm{Al}+\mathrm{Li}$ alloys. For $\mathrm{Zn}-\mathrm{Al}+\mathrm{Ag},{ }^{10} \mathrm{Zn}-\mathrm{Al}+\mathrm{Cu},{ }^{11,17}$ and $\mathrm{Zn}-\mathrm{Al}+\mathrm{Na},{ }^{12}$ addition of $\mathrm{Ag}, \mathrm{Cu}$, and $\mathrm{Na}$ resulted in creation of $\mathrm{Ag}-\mathrm{Zn}, \mathrm{Cu}-\mathrm{Zn}$, and $\mathrm{NaZn}_{13}$ IMC, respectively, reducing the diffusion of $\mathrm{Zn}$ by bonding it with $\mathrm{Ag}, \mathrm{Cu}$ or $\mathrm{Na}$. The $n$ value for $\mathrm{CuZn}_{4}$ and CuZn was 0.5 , meaning that the reaction was controlled by volume diffusion. The growth rate $k$ reduced with increasing $\mathrm{Li}$ content in the $\mathrm{Zn}-\mathrm{Al}+\mathrm{Li}$ alloys for all IMCs $\left(\mathrm{CuZn}, \mathrm{Cu}_{5} \mathrm{Zn}_{8}\right.$, and $\mathrm{CuZn}_{4}$ phases). The same situation was observed for the $\mathrm{CuZn}_{4}$ phase for $\mathrm{Zn}-\mathrm{Al}+\mathrm{Na},{ }^{12}$ but for the $\mathrm{Cu}_{5} \mathrm{Zn}_{8}$ phase, $k$ remained at the same level $(0.5)$ with increasing $\mathrm{Na}$ content. In the case of the $\mathrm{Cu}_{5} \mathrm{Zn}_{8}$ phase, addition of $\mathrm{Na}$ to $\mathrm{Zn}-\mathrm{Al}$ alloys had no influence on the growth rate, meaning that, for shorter time, the $\mathrm{Cu}_{5} \mathrm{Zn}_{8}$ phase grows at the same rate and the only change is the diffusion character. A different character was observed for $\mathrm{Zn}-\mathrm{Al}+\mathrm{Li}$ alloys for the $\mathrm{Cu}_{5} \mathrm{Zn}_{8}$ phase. With increasing $\mathrm{Li}$ content, the growth rate reduced, causing lower thickness for short spreading times (up to $15 \mathrm{~min}$ ), as shown in Fig. 3. 

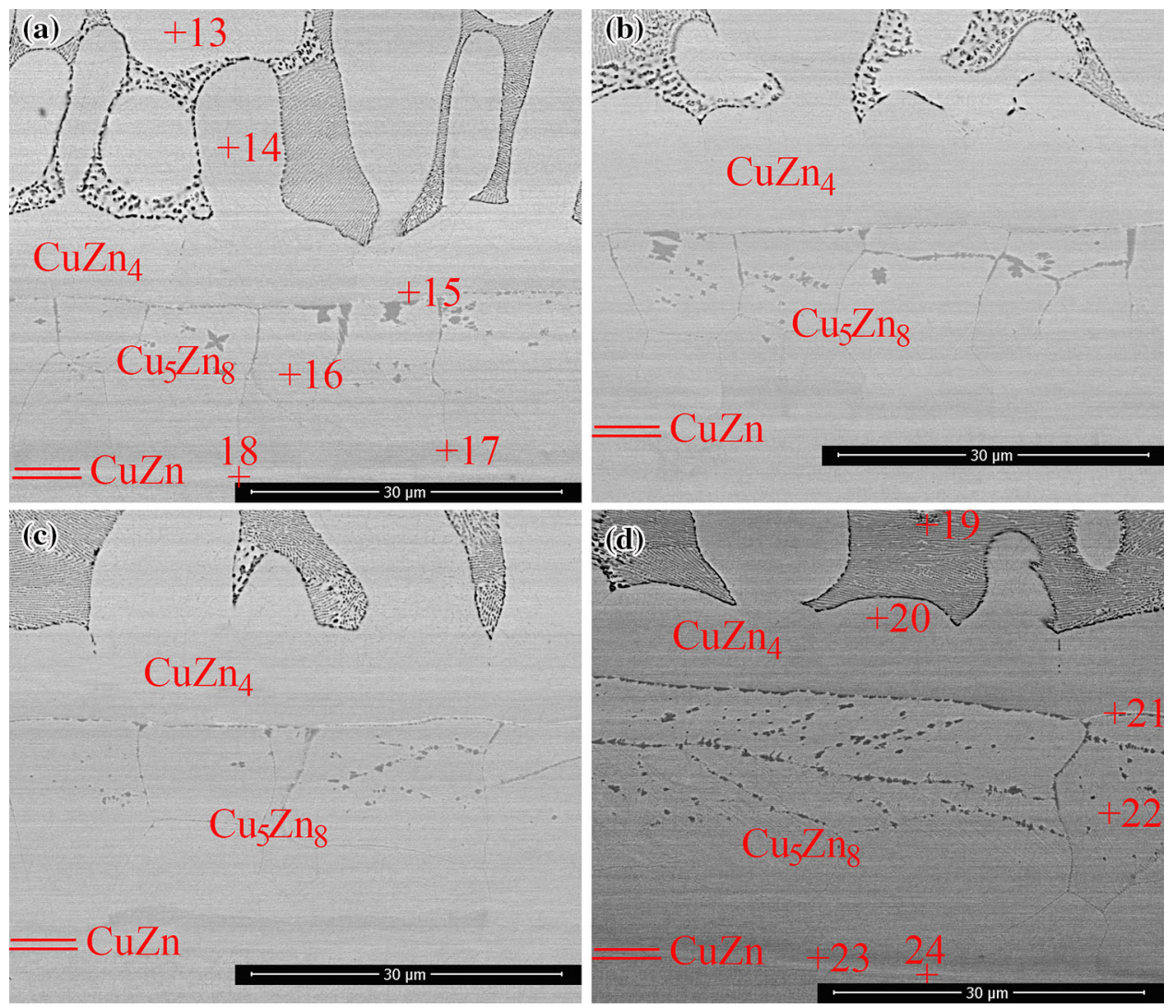

Fig. 5. Microstructure of interfaces on cross-sections of $\mathrm{Zn}$-Al alloy with $0.2 \% \mathrm{Li}$ on Cu substrate after spreading test for 8 min at temperature of (a) $475^{\circ} \mathrm{C}$, (b) $500^{\circ} \mathrm{C}$, (c) $525^{\circ} \mathrm{C}$, and (d) $550^{\circ} \mathrm{C}$, with IMCs and EDS analysis points marked (values presented in Table I).
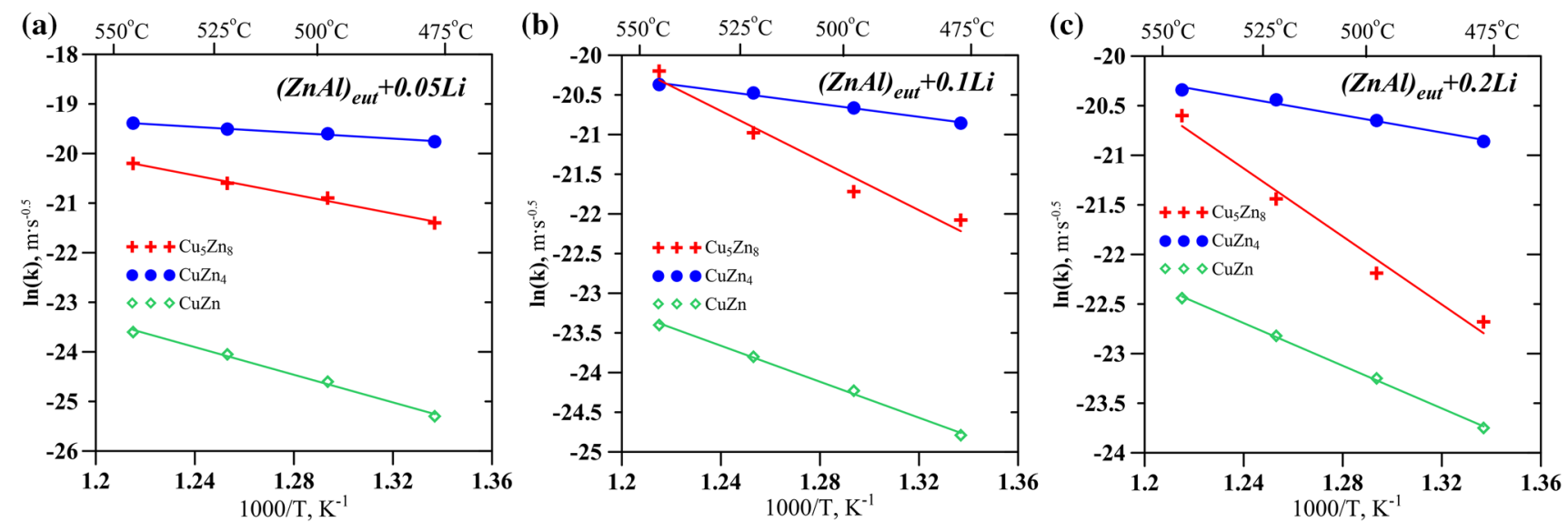

Fig. 6. Growth kinetics of IMC versus temperature for $\mathrm{Zn}-\mathrm{Al}+\mathrm{Li}$ alloys with (a) $0.05 \mathrm{wt} . \%$, (b) 0.1 wt.\%, and (c) 0.2 wt. \% Li addition.

The microstructure of $\mathrm{Zn}-\mathrm{Al}$ with $0.2 \% \mathrm{Li}$ on a $\mathrm{Cu}$ substrate after spreading for $8 \mathrm{~min}$ at temperature of (a) $475^{\circ} \mathrm{C}$, (b) $500^{\circ} \mathrm{C}$, (c) $525^{\circ} \mathrm{C}$, and (d) $550^{\circ} \mathrm{C}$ is presented in Fig. 5. The microstructure after the spreading test was similar for all Li contents, and IMC layers increased with increasing temperature. Similar to Refs. 10-12, 17, and 22, three IMCs (CuZn, $\mathrm{Cu}_{5} \mathrm{Zn}_{8}$, and $\mathrm{CuZn}$, phases) formed from the $\mathrm{Cu}$ substrate at the interface. For all temperatures, the observed IMC layers looked the same: a smooth thin $\mathrm{CuZn}$ layer, a thick $\mathrm{Cu}_{5} \mathrm{Zn}_{8}$ layer with $\mathrm{Al}$ content caused by the fast path for $\mathrm{Cu}$ diffusion, and a $\mathrm{CuZn}_{4}$ layer with scallops in the top. EDS analysis revealed the presence of more than 10 at.\% $\mathrm{Al}$, not only in the $\mathrm{Cu}_{5} \mathrm{Zn}_{8}$ but also in the CuZn phase, in accordance with the $\mathrm{Al}-\mathrm{Cu}-\mathrm{Zn}$ phase diagram, ${ }^{19}$ which shows that $\mathrm{Al}$ dissolves in the $\mathrm{Cu}_{5} \mathrm{Zn}_{8}$ and $\mathrm{CuZn}$ phases. Close to the interface from the solder side, EDS analysis at points 13 (Fig. 5a) and 19 (Fig. 5d) showed higher amounts of $\mathrm{Al}$ and also 
dissolved $\mathrm{Cu}$. For all temperatures, in the $\mathrm{Cu}_{5} \mathrm{Zn}_{8}$ layer, there is a fast path for $\mathrm{Cu}$ diffusion, with EDS analysis revealing higher amounts of $\mathrm{Al}$ compared with the rest of the $\mathrm{Cu}_{5} \mathrm{Zn}_{8}$ layer. To identify the growth kinetics of the IMC layer and the activation energy, the dependence of $\ln k$ on inverse temperature is presented in Fig. $6 \mathrm{a}-\mathrm{c}$ for the $\mathrm{Zn}-\mathrm{Al}+\mathrm{Li}$ alloys. The activation energies calculated for $\beta$-CuZn, $\gamma-\mathrm{Cu}_{5} \mathrm{Zn}_{8}$, and $\varepsilon-\mathrm{CuZn} \mathrm{n}_{4}$ are presented in Table II. The activation energies for the $\beta$ - and $\gamma$-phases for the $\mathrm{Zn}-\mathrm{Al}+\mathrm{Li}$ alloys are much higher than for eutectic $\mathrm{Zn}-\mathrm{Al},{ }^{10}$ and are only similar for the $\varepsilon$-phase. With increasing $\mathrm{Li}$ addition to the $\mathrm{Zn}-\mathrm{Al}$ alloy, the activation energy is reduced for $\beta$-phase, but at the same time increases for $\gamma$ - and $\varepsilon$-phases, inhibiting nucleation and growth of these phases at the interface. This confirms that $\mathrm{Li}$ addition has an effect on the formation of IMCs. A similar effect was observed for $\mathrm{Zn}-\mathrm{Al}$ with $\mathrm{Ag}^{10}$ and $\mathrm{Na},{ }^{12}$ indicating that the IMC precipitates formed with $\mathrm{Zn}$ in the solder had a significant effect on the growth kinetics of IMC layers at the interface.

Table II. Activation energy of IMCs of $\mathrm{Zn}$-Al alloys with different $L i$ contents after spreading test

\begin{tabular}{|c|c|c|}
\hline Alloy & IMC & $\begin{array}{l}\text { Activation energy } \\
\quad\left(\mathbf{k J ~ \mathrm { mol } ^ { - 1 } )}\right.\end{array}$ \\
\hline \multirow[t]{3}{*}{$\mathrm{Zn}-\mathrm{Al}-0.05 \mathrm{Li}$} & $\beta$ & 115.9 \\
\hline & $\gamma$ & 79.9 \\
\hline & $\varepsilon$ & 24.6 \\
\hline \multirow[t]{3}{*}{$\mathrm{Zn}-\mathrm{Al}-0.1 \mathrm{Li}$} & $\beta$ & 94.3 \\
\hline & $\gamma$ & 129.9 \\
\hline & $\varepsilon$ & 33.9 \\
\hline \multirow[t]{3}{*}{$\mathrm{Zn}-\mathrm{Al}-0.2 \mathrm{Li}$} & $\beta$ & 89.3 \\
\hline & $\gamma$ & 142.6 \\
\hline & $\varepsilon$ & 36.4 \\
\hline
\end{tabular}

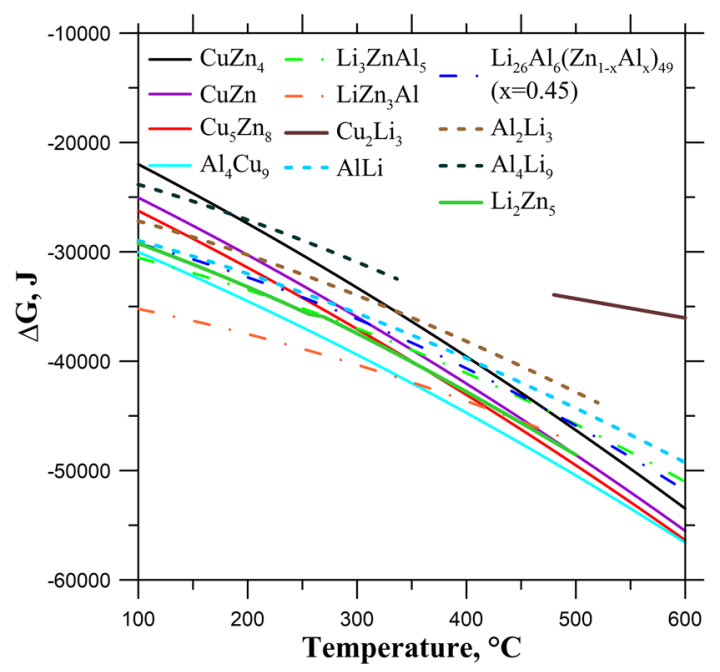

Fig. 7. Temperature dependence of Gibbs energy of IMCs, calculated with ThermoCalc using thermodynamic data from Refs. 13 and 19.
Considering the spreading process on a $\mathrm{Cu}$ substrate, one is dealing with two systems. One is $\mathrm{Al}-$ $\mathrm{Zn}-\mathrm{Li}$, which corresponds to the phases formed in the solder, and the second is $\mathrm{Al}-\mathrm{Cu}-\mathrm{Zn}$, for the IMC layer formed at the interface. Taking into account the Gibbs energies of formation of the intermetallics, as discussed in Ref. 10, calculations using ThermoCalc and the thermodynamic parameters from Ref. 13 for the Al-Li-Zn system and from Ref. 19 for the $\mathrm{Al}-\mathrm{Cu}-\mathrm{Zn}$ system are presented in Fig. 7. These calculations indicate that $\mathrm{LiZn}_{3} \mathrm{Al}$ has the lowest Gibbs energy, which means it is thermodynamically the most stable in the solder, and the $\mathrm{Al}_{4} \mathrm{Cu}_{9}$ correlates to the $\mathrm{Cu}_{5} \mathrm{Zn}_{8}$ at the interface. Precipitates of the $\mathrm{Al}-\mathrm{Li}, \mathrm{Li}-\mathrm{Zn}$, and $\mathrm{Al}-\mathrm{Li}-\mathrm{Zn}$ systems were confirmed by their observation in the microstructure of $\mathrm{Zn}-\mathrm{Al}-\mathrm{Li}$ cast alloys, ${ }^{7}$ but without literature and crystal structure data, it is impossible to identify the IMC precipitates occurring for cast $\mathrm{Zn}-\mathrm{Al}-\mathrm{Li}$ alloys. Selected-area electron diffraction (SAED) analysis made it possible to identify and confirm the occurrence of $\mathrm{AlLi}$ and $\mathrm{Al}_{3} \mathrm{Li}$ precipitate phases. However, the very small precipitates inside the $\mathrm{Zn}$ area were not identified. The soldering process can be divided into two stages: first, dissolution of the $\mathrm{Cu}$ substrate by liquid solder, and second, crystallization and growth controlled by diffusion of $\mathrm{Cu}$ and $\mathrm{Zn}$ to the interface. During the crystallization at the interface, the growth of three IMC layers $\left(\mathrm{CuZn}, \mathrm{Cu}_{5} \mathrm{Zn}_{8}\right.$, and $\mathrm{CuZn}_{4}$ ) inside the $\mathrm{Cu}_{5} \mathrm{Zn}_{8}$ in places with fast paths for $\mathrm{Cu}$ diffusion starts the formation of $\mathrm{Al}_{4} \mathrm{Cu}_{9}$, which is in agreement with the $\mathrm{Al}-\mathrm{Cu}-\mathrm{Zn}$ phase diagram. ${ }^{19}$ Further increases in time and temperature lead to growth of most of the $\mathrm{Cu}_{5} \mathrm{Zn}_{8}$ layer, as presented in Figs. 2-6. Nevertheless, other factors are also important in the nucleation and growth of phases during wetting. These include dissolving or high diffusion of $\mathrm{Cu}$ to the interface and solder. This reasoning is more suitable for aging of already existing solid phases, ${ }^{24}$ where under conditions of constant temperature over time the system tends to the minimum Gibbs energy, thus promoting growth of the least energetic phase at the expense of more energetic phases. Lee et al. ${ }^{25}$ and Wang et al. ${ }^{26}$ showed that the phase with highest energy of formation is consumed by phases with lower energy under the specific condition that diffusion, not stability of the phases, plays the decisive role. Considering this issue for the binary $\mathrm{Al}-\mathrm{Zn}$ system, where growth of the Al-rich phase at grain boundaries is controlled by volume diffusion in the matrix phase, ${ }^{27}$ as well as other factors such as increased $\mathrm{Li}$ addition and $\mathrm{Cu}$ diffusion from the substrate, the problem becomes more complicated. However, Li addition to eutectic $\mathrm{Zn}-\mathrm{Al}$ is sufficient to inhibit growth of the phase at the solder-substrate interface. At the same time, it significantly improves mechanical properties and does not affect the melting temperature of the alloy. The calculated diffusion rates for $\mathrm{Al}$ and $\mathrm{Zn}$ elements in the $\mathrm{Cu}$ 

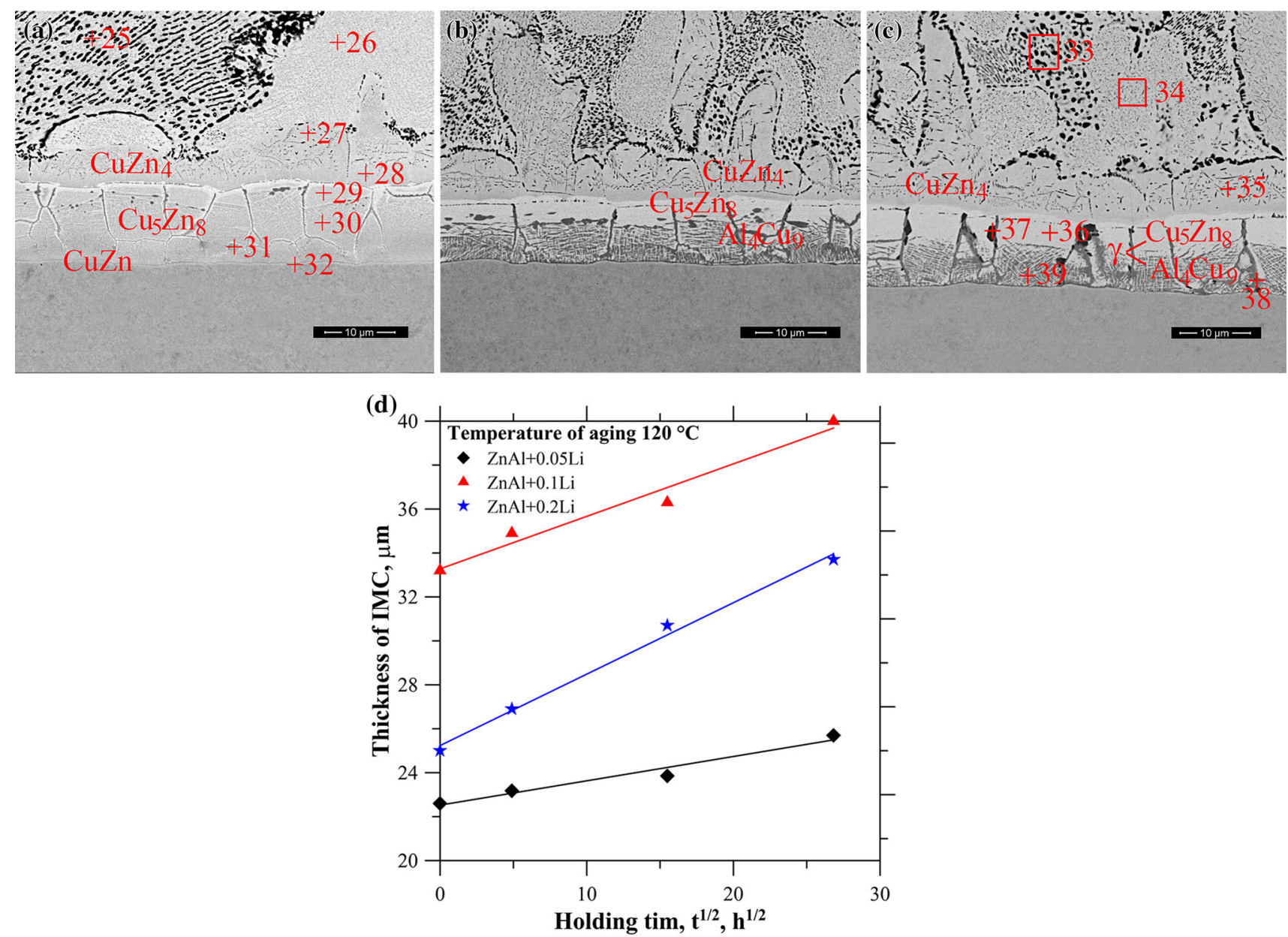

Fig. 8. Microstructure of $\mathrm{Zn}-\mathrm{Al}+0.05 \mathrm{Li}$ after aging at temperature of $250^{\circ} \mathrm{C}$ for (a) 1 day, (b) 10 days, and (c) 30 days, and (d) dependence of IMC layer thickness on time for $\mathrm{Zn}-\mathrm{Al}+\mathrm{Li}$ alloys after aging at temperature of $120^{\circ} \mathrm{C}$, with IMCs and EDS analysis points marked (values presented in Table I).

Table III. IMC growth properties during aging in $\mathrm{Cu} /$ solid $\mathrm{Zn}$-Al alloys with $\mathrm{Li}$ addition

$$
k\left(\mathrm{~m} \mathrm{~s}^{-1 / 2}\right)
$$

\begin{tabular}{|c|c|c|c|c|c|}
\hline Alloy & $120^{\circ} \mathrm{C}$ & $170^{\circ} \mathrm{C}$ & $250^{\circ} \mathrm{C}$ & $k_{0}\left(\mathrm{~m} \mathrm{~s}^{-1 / 2}\right)$ & $\begin{array}{c}\text { Activation energy, } \\
\qquad\left(\mathbf{k J ~ m ^ { - 1 } )}\right.\end{array}$ \\
\hline $\mathrm{Zn}-\mathrm{Al}+0.05 \mathrm{Li}$ & $1.11 \times 10^{-10}$ & $2.76 \times 10^{-9}$ & $2.24 \times 10^{-8}$ & 0.230 & 69.2 \\
\hline $\mathrm{Zn}-\mathrm{Al}+0.1 \mathrm{Li}$ & $2.39 \times 10^{-10}$ & $3.11 \times 10^{-9}$ & $2.32 \times 10^{-8}$ & 0.037 & 61.1 \\
\hline $\mathrm{Zn}-\mathrm{Al}+0.2 \mathrm{Li}$ & $3.25 \times 10^{-10}$ & $3.47 \times 10^{-9}$ & $3.02 \times 10^{-8}$ & 0.028 & 59.3 \\
\hline
\end{tabular}

substrate at $450^{\circ} \mathrm{C}$ are $5.3 \times 10^{14} \mathrm{~cm}^{2} \mathrm{~s}^{-1}$ and $3.9 \times 10^{14} \mathrm{~cm}^{2} \mathrm{~s}^{-1}$, respectively. ${ }^{21}$ Furthermore, the reaction activity between the elements $\mathrm{Al}$ and $\mathrm{Cu}$ is strong, ${ }^{28}$ in agreement with the calculations shown in Fig. 7. However, in the case of a $\mathrm{Cu} / \mathrm{Zn}$ $3 \mathrm{Al} / \mathrm{Cu}$ joint, ${ }^{21} \mathrm{Al}-\mathrm{Cu}$ reaction products were not observed, which may be caused by the low $\mathrm{Al}$ content in the $\mathrm{Zn}-\mathrm{Al}$ filler metal, and because the $\mathrm{Al}$ element is mainly dissolved in the thick $\mathrm{Cu}_{5} \mathrm{Zn}_{8}$ IMC layer. ${ }^{21}$ This study showed that 5.3 wt.\% content of $\mathrm{Al}$ is sufficient for formation of particles of $\mathrm{Al}_{4} \mathrm{Cu}_{9}$ in places with fast paths for $\mathrm{Cu}$ diffusion formed during the spreading test.

\section{Aging Treatment}

Cross sections of $\mathrm{Zn}-\mathrm{Al}$ with $0.05,0.1$, and $0.2 \mathrm{Li}$ content after the spreading test at $500^{\circ} \mathrm{C}$ for $1 \mathrm{~min}$ were aged for 1 day, 10 days, and 30 days at temperature of $120^{\circ} \mathrm{C}, 170^{\circ} \mathrm{C}$, and $250^{\circ} \mathrm{C}$. The selected samples were chosen after spreading for $1 \mathrm{~min}$, to show the effect of aging time and 

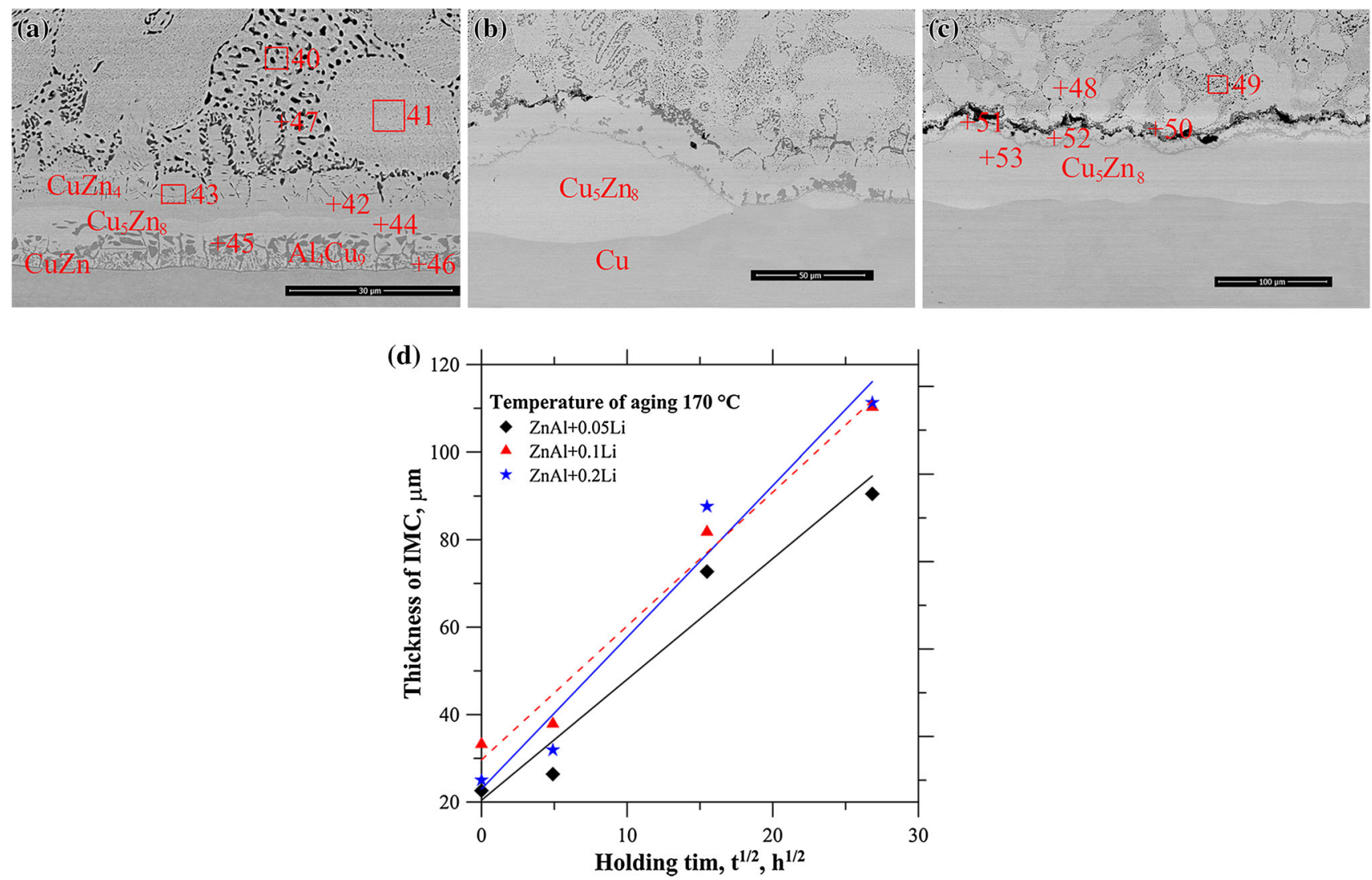

Fig. 9. Microstructure of $\mathrm{Zn}-\mathrm{Al}+0.05 \mathrm{Li}$ after aging at temperature of $250^{\circ} \mathrm{C}$ for (a) 1 day, (b) 10 days, and (c) 30 days, and (d) dependence of $\mathrm{IMC}$ layer thickness on time for $\mathrm{Zn}-\mathrm{Al}+\mathrm{Li}$ alloys after aging at temperature of $170^{\circ} \mathrm{C}$, with IMCs and EDS analysis points marked (values presented in Table I).

temperature on changes occurring to the IMCs at the interface. The microstructures obtained after aging were similar for all the $\mathrm{Zn}-\mathrm{Al}+\mathrm{Li}$ alloys, with changes of the thickness of layers at the interface with differing $\mathrm{Li}$ content. The microstructures of $\mathrm{Zn}$ $\mathrm{Al}+0.05 \mathrm{Li}$, after aging at $120^{\circ} \mathrm{C}$ for 1 day, 10 days, and 30 days, are presented in Fig. 8. Three layers are observed at the interface: $\beta(\mathrm{CuZn}), \varepsilon\left(\mathrm{CuZn}_{4}\right)$, and $\gamma\left(\mathrm{Cu}_{5} \mathrm{Zn}_{8}\right.$ and $\left.\mathrm{Al}_{4} \mathrm{Cu}_{9}\right)$. $\varepsilon$ and $\gamma$ grow as time increases. In the $\gamma$ layer, fast $\mathrm{Cu}$ diffusion paths formed during the spreading test, forming $\mathrm{Al}_{4} \mathrm{Cu}_{9}$ particles that grew with increasing time and concentrated at the bottom of the layer from the $\mathrm{Cu}$ substrate side. According to the $\mathrm{Al}-\mathrm{Cu}-\mathrm{Zn}$ phase diagram $^{19}$ and the calculation results presented in Fig. 7, the most stable, $\mathrm{Al}_{4} \mathrm{Cu}_{9}$ phase formed at the interface. EDS analysis confirmed high concentration of $\mathrm{Al}$ at the interface (Table I). During aging at $120^{\circ} \mathrm{C}$, the diffusion rate of $\mathrm{Al}$ element in the $\mathrm{Cu}$ substrate was slightly higher than that of $\mathrm{Zn}$ element, ${ }^{21}$ which is sufficient for formation of particles of $\mathrm{Al}_{4} \mathrm{Cu}_{9}$ phase. The same situation was observed for $\mathrm{Zn}-\mathrm{Al}+\mathrm{Na}$ alloys, ${ }^{12}$ meaning that the formed $\mathrm{Li}$ or $\mathrm{Na}$ IMCs had no effect on the creation of $\mathrm{Al}_{4} \mathrm{Cu}_{9}$ phase inside the $\mathrm{Cu}_{5} \mathrm{Zn}_{8}$ layer during aging at $120^{\circ} \mathrm{C}$. However, with increased Li content in the $\mathrm{Zn}-\mathrm{Al}+\mathrm{Li}$ alloy, the IMC layers at the interface grew. The opposite effect was observed for $\mathrm{Zn}-\mathrm{Al}+\mathrm{Na}$ alloys. ${ }^{12}$ The growth rate during aging at $120^{\circ} \mathrm{C}$ increased by one order of magnitude with higher Li content, as shown in Table III.

The microstructure of $\mathrm{Zn}-\mathrm{Al}+0.05 \mathrm{Li}$, after aging at $170^{\circ} \mathrm{C}$ for 1 day, 10 days, and 30 days, is presented in Fig. 9. After 1 day (Fig. 9a), the microstructures of all the $\mathrm{Zn}-\mathrm{Al}+\mathrm{Li}$ alloys was similar to those after aging at $120^{\circ} \mathrm{C}$, that is, two IMC layers ( $\varepsilon$ and $\gamma$ ), with particles of $\mathrm{Al}_{4} \mathrm{Cu}_{9}$ inside the $\mathrm{Cu}_{5} \mathrm{Zn}_{8}$ layer, as confirmed by EDS analysis (Table I). However, after 10 days (Fig. 9b), the microstructure changed. The $\varepsilon$-phase had been consumed by the $\gamma$-phase, and particles of the $\mathrm{Al}_{4} \mathrm{Cu}_{9}$ phase had transformed to $\mathrm{Cu}_{5} \mathrm{Zn}_{8}$. This effect is connected with the reducing concentration of $\mathrm{Al}$ close to the interface, which caused increasing diffusion of $\mathrm{Cu}$ to the solder and a greater amount of free $\mathrm{Zn}$, leading to growth of the $\mathrm{Cu}_{5} \mathrm{Zn}_{8}$ layer with $\mathrm{Al}$ dissolving within. Independent of the stability of phases, the continuous diffusion of $\mathrm{Cu}$ to the interface caused changes and the growth of a less stable phase, as observed and described in Refs. 12 and 26. Wang et al. ${ }^{26}$ found that, under specific conditions (for samples after soldering with an extremely fast cooling rate of $\left.46^{\circ} \mathrm{C} \mathrm{s}^{-1}\right), \mathrm{Cu}_{6} \mathrm{Sn}_{5}$ and $\mathrm{Cu}_{3} \mathrm{Sn}$ started to form during aging at $170^{\circ} \mathrm{C}$ for eutectic $\mathrm{Sn}-\mathrm{Zn}$ with a $\mathrm{Cu}$ substrate (after 29 days). The $\mathrm{Cu}_{5} \mathrm{Zn}_{8}$ phase was the most stable. However, 

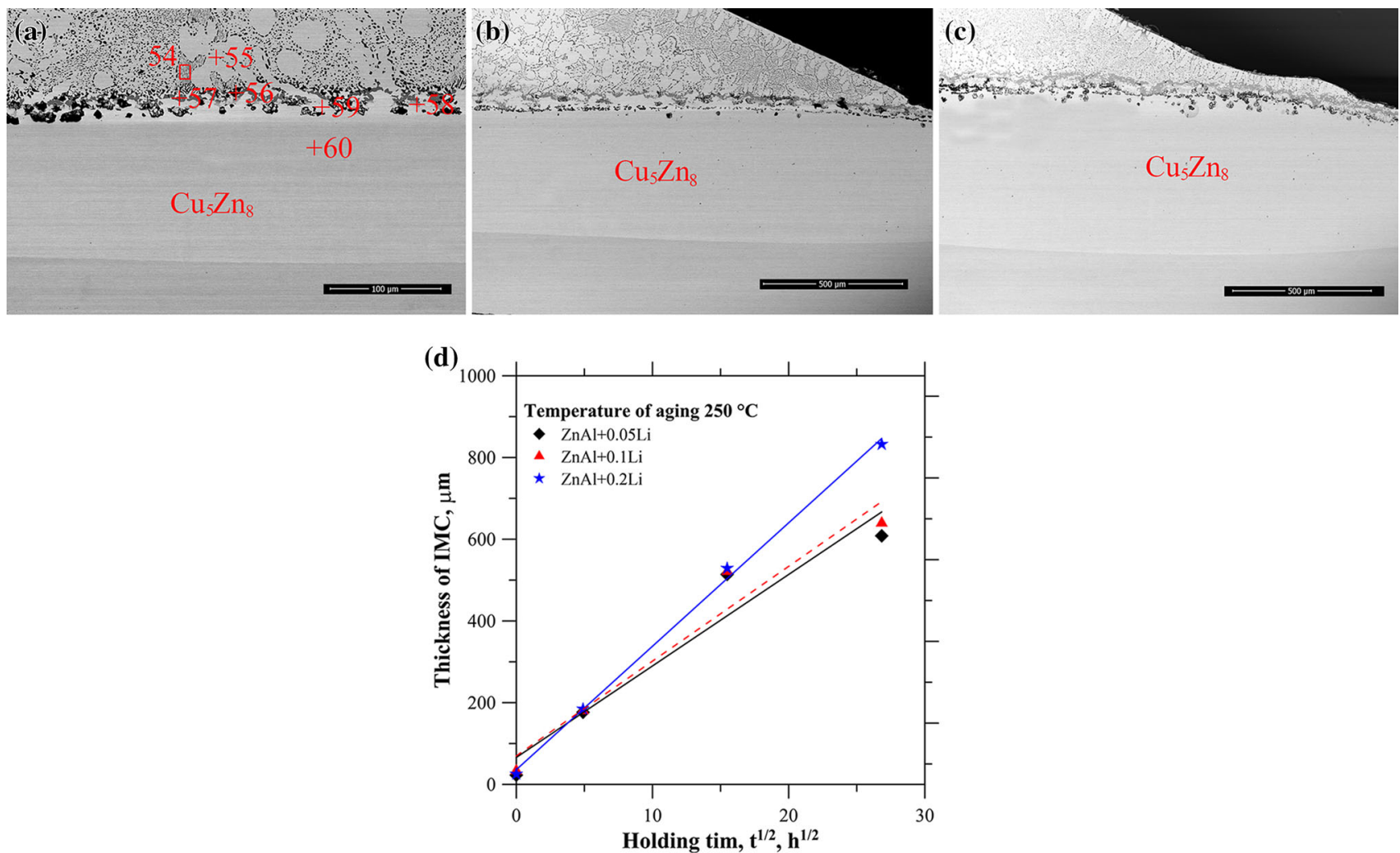

Fig. 10. Microstructure of $\mathrm{Zn}-\mathrm{Al}+0.05 \mathrm{Li}$ after aging at temperature of $250^{\circ} \mathrm{C}$ for (a) 1 day, (b) 10 days, and (c) 30 days, and (d) dependence of IMC layer thickness on time for $\mathrm{Zn}-\mathrm{Al}+\mathrm{Li}$ alloys after aging at temperature of $250^{\circ} \mathrm{C}$, with IMCs and EDS analysis points marked (values presented in Table I).

for furnace-cooled samples, this was not observed. The same disappearance of the $\mathrm{Al}_{4} \mathrm{Cu}_{9}$ phase after 10 days was observed for $\mathrm{Zn}-\mathrm{Al}+\mathrm{Na}$. This means that the same mechanisms take place independent of the additive. Nevertheless, addition of $\mathrm{Li}$ and $\mathrm{Na}$ has different influences on blocking the growth of IMC layers at the interface.

The microstructure of $\mathrm{Zn}-\mathrm{Al}+0.05 \mathrm{Li}$, after aging at $250^{\circ} \mathrm{C}$ for 1 day, 10 days, and 30 days, is presented in Fig. 10. After 1 day (Fig. 10a), only one layer $\left(\mathrm{Cu}_{5} \mathrm{Zn}_{8}\right)$ was observed, as confirmed by EDS analysis. A small particle of $\mathrm{Al}_{4} \mathrm{Cu}_{9}$ phase occurred in the top of the $\mathrm{Cu}_{5} \mathrm{Zn}_{8}$ layer. With increasing time, the $\mathrm{Cu}_{5} \mathrm{Zn}_{8}$ layer grew, and became thicker with increasing Li content (Fig. 10d). Higher growth of IMCs was observed for aging at $250^{\circ} \mathrm{C}$, which correlates with the higher diffusion of $\mathrm{Cu}$ and $\mathrm{Zn}$ to the interface, causing the formation of the $\mathrm{Cu}_{5} \mathrm{Zn}_{8}$ layer. XRD analysis did not identify the occurrence of various IMC precipitates at the top of the $\mathrm{Cu}_{5} \mathrm{Zn}_{8}$ layer. Compared with $\mathrm{Li}$ addition, increasing $\mathrm{Na}$ content caused a reduction in the growth of the $\mathrm{Cu}_{5} \mathrm{Zn}_{8}$ layer, during aging at $250^{\circ} \mathrm{C}$. $^{12} \mathrm{Zhu}$ et al. ${ }^{29}$ found that, for $90 \mathrm{Zn}-7 \mathrm{Al}-3 \mathrm{Cu}$ (wt.\%) alloy prepared as thin films, the nanophase (Zn) decomposed during aging at $220^{\circ} \mathrm{C}$ for $105 \mathrm{~h}$. As products of the eutectoid decomposition of the nanophase $(\mathrm{Zn})$, the amount of the two phases [eutectic $\mathrm{Zn}-5.3 \mathrm{Al}$ and nanophase $\tau^{\prime} 10 \mathrm{Zn}-35 \mathrm{Al}-55 \mathrm{Cu}$ (wt.\%)] increased during further aging. ${ }^{29}$ In this study, XRD analysis could not identify the $\tau^{\prime}$-phase. This could be because the phase is small, as the EDS analysis at point 57 revealed the possibility of the presence of fine precipitates of this $\tau^{\prime}$-phase. Comparing the effects of addition of $\mathrm{Li}$ versus $\mathrm{Na}^{12}$ to eutectic $\mathrm{Zn}$-Al during aging, differences were observed. Increased $\mathrm{Li}$ content did not block growth of IMC layers, resulting in increased thickness, whereas increasing $\mathrm{Na}$ addition led to a reduction in the thickness of IMC layers. Confirming the influence of $\mathrm{Li}$, the activation energy (Table III) reduced with increasing $\mathrm{Li}$ addition to $\mathrm{Zn}-\mathrm{Al}$ alloy, as opposed to increasing with additional $\mathrm{Na}\left(65.69 \mathrm{~kJ} \mathrm{~mol}^{-1}\right.$, $66.20 \mathrm{~kJ} \mathrm{~mol}^{-1}$, and $73.11 \mathrm{~kJ} \mathrm{~mol}^{-1}$ for $0.2 \mathrm{wt} . \%$, 0.5 wt. $\%$, and 1.0 wt. $\% \mathrm{Na}$ content ${ }^{12}$ ). Nevertheless, the activation energy obtained for the $\gamma$-phase during aging was much higher compared with the values of $44.37 \mathrm{~kJ} \mathrm{~mol}^{-1}$ for $\mathrm{Zn}-4 \mathrm{Al}^{17}$ and $39.03 \mathrm{~kJ} \mathrm{~mol}^{-1}$ for $\mathrm{Zn}-4 \mathrm{Al}-1 \mathrm{Cu}{ }^{17}$ For the growth rate during aging, the effect is more obvious. For aging at $120^{\circ} \mathrm{C}$, the lowest value of $1.11 \times 10^{-10} \mathrm{~m} \mathrm{~s}^{-1 / 2}$ was obtained for $\mathrm{Zn}-\mathrm{Al}$ $0.05 \mathrm{Li}$, compared with $5.05 \times 10^{-11} \mathrm{~m} \mathrm{~s}^{-1 / 2}$ for $\mathrm{Zn}$ $\mathrm{Al}-1.0 \mathrm{Na} .{ }^{12}$ This difference was reduced for aging at $170^{\circ} \mathrm{C}$, with the lowest value of $2.76 \times 10^{-9} \mathrm{~m} \mathrm{~s}^{-1 / 2}$ being obtained for $\mathrm{Zn}-\mathrm{Al}-0.05 \mathrm{Li}$, compared with $1.72 \times 10^{-9} \mathrm{~m} \mathrm{~s}^{-1 / 2}$ for $\mathrm{Zn}-\mathrm{Al}-1.0 \mathrm{Na}{ }^{12}$ The difference was even greater for aging at $250^{\circ} \mathrm{C}$, with the 
lowest value of $2.24 \times 10^{-8} \mathrm{~m} \mathrm{~s}^{-1 / 2}$ being obtained for $\mathrm{Zn}-\mathrm{Al}-0.05 \mathrm{Li}$, compared with $1.40 \times 10^{-8} \mathrm{~m} \mathrm{~s}^{-1 / 2}$ for $\mathrm{Zn}-\mathrm{Al}-1.0 \mathrm{Na}{ }^{12}$ Taking into account all the parameters, $\mathrm{Li}$ addition to $\mathrm{Zn}-\mathrm{Al}^{12}$ blocks growth of IMC layers at the interface during aging, but $\mathrm{Na}$ addition has a much more significant effect, as observed at $250^{\circ} \mathrm{C}$ in the IMC layer thickness $(586 \mu \mathrm{m}$ for $\mathrm{Zn}-\mathrm{Al}-0.05 \mathrm{Li}$, compared with $399 \mu \mathrm{m}$ for $\mathrm{Zn}-\mathrm{Al}-1.0 \mathrm{Na}){ }^{12}$

\section{CONCLUSIONS}

Considering the conclusion of Ref. 30, further research and development for Zn-based high-temperature solders is essential for replacement of conventional $\mathrm{Pb}$-based high-temperature solders. The proposed $\mathrm{Zn}-\mathrm{Al}$ alloys have applications in the automotive, refrigeration, air, and space industries, and the following conclusions can be drawn:

- $\mathrm{Li}$ addition to eutectic $\mathrm{Zn}-\mathrm{Al}$ alloy caused the spreading area to increase, with a reduction in the thickness of IMC layers at the interface during spreading tests as a function of temperature and time.

- Identification of IMCs from the $\mathrm{Cu}-\mathrm{Zn}$ system, such as $\mathrm{CuZn}, \mathrm{Cu}_{5} \mathrm{Zn}_{8}$, and $\mathrm{CuZn}_{4}$ phases, formed at the interface was possible based on XRD analysis and SEM and TEM microstructure analyses of this alloy. Occurrence of IMCs from the $\mathrm{Al}-\mathrm{Li}, \mathrm{Li}-$ $\mathrm{Zn}$, and $\mathrm{Al}-\mathrm{Li}-\mathrm{Zn}$ systems was also confirmed, but without literature and crystal structure data, it is impossible to identify the IMC precipitates occurring for the cast $\mathrm{Zn}-\mathrm{Al}-\mathrm{Li}$ alloys.

- For the CuZn and $\mathrm{CuZn}_{4}$ phases, linear dependence of the growth of IMC over time was observed. Therefore, assuming that the exponent $n=1 / 2$, this means that we have volume diffusion. However, for the $\mathrm{Cu}_{5} \mathrm{Zn}_{8}$ phase, it was $n \gg 1 / 2$, which corresponds to a chemical reaction in the formation process of the $\mathrm{Cu}_{5} \mathrm{Zn}_{8}$ layer. The highest activation energy was obtained for the $\mathrm{Cu}_{5} \mathrm{Zn}_{8}$ phase, being $142.6 \mathrm{~kJ} / \mathrm{mol}$ for $\mathrm{Zn}-\mathrm{Al}-0.2 \mathrm{Li}$ (wt.\%).

- $\mathrm{Li}$ addition to eutectic $\mathrm{Zn}-\mathrm{Al}$ did not block the growth of IMC layers during aging treatment, even resulting in faster growth with increasing $\mathrm{Li}$ content, which also correlated with the reduction in the activation energy of the $\mathrm{Cu}_{5} \mathrm{Zn}_{8}$ phase with increasing $\mathrm{Li}$ content. The highest growth was observed for aging at $250^{\circ} \mathrm{C}$, where the $\mathrm{Cu}_{5} \mathrm{Zn}_{8}$ phase was dominant, which is in accordance with the Gibbs energy calculated for this phase.

\section{ACKNOWLEDGEMENTS}

This work was financed by Ministry of Science and High Education of Poland Grant IP2014 011473 "Effect of addition of $\mathrm{Na}, \mathrm{Li}$ and $\mathrm{Si}$ to eutectic $\mathrm{ZnAl}$ alloys on phenomena occurring at the interface of soldered joints," in the years 2015-2017.

\section{OPEN ACCESS}

This article is distributed under the terms of the Creative Commons Attribution 4.0 International License (http://creativecommons.org/licenses/by/4.0/), which permits unrestricted use, distribution, and reproduction in any medium, provided you give appropriate credit to the original author(s) and the source, provide a link to the Creative Commons license, and indicate if changes were made.

\section{REFERENCES}

1. B.C. Wei, C.Q. Chen, Z. Huang, and Y.G. Zhang, Mater. Sci. Eng. A 280, 161 (2000).

2. Y. Deng, J. Yang, S. Li, J. Zhang, and X. Zhang, Trans. Nonferr. Met. Soc. 24, 1653 (2014).

3. R. Li, F. Pan, B. Jiang, Q. Yang, and A. Tang, Mater. Des. 46, $922(2013)$

4. R. Li, F. Pan, B. Jiang, H. Dong, and Q. Yang, Mater. Sci. Eng. A 562, 33 (2013).

5. Y. Kim, J. Kim, H. Yu, J. Choi, and H. Son, J. Alloys Compd. 583, 15 (2014).

6. H. Son, Y. Kim, D. Kim, J. Kim, and H. Yu, J. Alloys Compd. 564, 130 (2013).

7. T. Gancarz and G. Cempura, Mater. Des. 104, 51 (2016). doi:10.1016/j.matdes.2016.05.

8. H. Qin, H. Zhang, and H. Wu, Mater. Sci. Eng. A 626, 322 (2015).

9. W. Hu, Y. Liu, D. Li, X. Zeng, and C. Xu, Phys. B 427, 85 (2013).

10. T. Gancarz, J. Pstruś, P. Fima, and S. Mosińska, J. Alloys Compd. 582, 313 (2014).

11. T. Gancarz, J. Pstruś, S. Mosińska, and S. Pawlak, Metall. Mater. Trans. A 47, 368 (2016).

12. T. Gancarz, J. Pstruś, and K. Berent, J. Mater. Eng. Perform. (2016). doi:10.1007/s11665-016-2075-7.

13. C. Guo, Y. Liang, C. Li, and Z. Du, Calphad 35, 54 (2011).

14. S.G. Protasova, O.A. Kogtenkova, B.B. Straumal, P. Zięba, and B. Baretzky, J. Mater. Sci. 46, 4349 (2011).

15. G. Zeng, S. McDonald, and K. Nogita, Microelectron. Reliab. 52, 1306 (2012).

16. N. Kang, H. Na, S. Kim, and C. Kang, J. Alloys Compd. 467, 246 (2009).

17. Y. Takaku, L. Felicia, I. Ohnuma, R. Kainuma, and K. Ishida, J. Electron. Mater. 37, 314 (2008).

18. T. Shimizu, H. Ishikawa, I. Ohnuma, and K. Ishida, J. Electron. Mater. 28, 1172 (1999).

19. V. Raghavan, J. Phase Equilib. Diff. 28, 183 (2007).

20. T. Gancarz, Fluid Phase Equilib. 427, 97 (2016). doi: 10.1016/j.fluid.2016.06.045.

21. Y. Xiao, M. Li, L. Wang, S. Huang, X. Du, and Z. Liu, Mater. Des. 73, 42 (2015).

22. K. Berent, J. Pstrus, and T. Gancarz, J. Mater. Eng. Perform. (2016). doi:10.1007/s11665-016-2074-8.

23. M. Date, T. Shoji, M. Fujiyoshi, K. Sato, and K.N. Tu, Scr. Metall. 51, 641 (2004).

24. Y.H. Zhu and J.J. Islas, J. Mater. Process. Technol. 66, 244 (1997).

25. H. Lee, S. Yoon, and B. Lee, J. Electron. Mater. 27, 1161 (1998).

26. J.Y. Wang, C.F. Lin, and C.M. Chen, Scr. Mater. 64, 633 (2011).

27. G. López, E. Mittemeijer, and B. Straumal, Acta Mater. 52, 4537 (2004).

28. J. Lee, K. Kim, K. Suganuma, J. Takenaka, and K. Hagio, Mater. Trans. 46, 2413 (2005).

29. Y. Zhu, W. Lee, and S. To, Mater. Charact. 52, 217 (2004).

30. M. Islam and A. Sharif, Reference Module in Materials Science and Materials (2016). doi:10.1016/B978-0-12803581-8.04012-1. 